\title{
PELAKSANAAN PENILAIAN FORMATIF DALAM PEMBELAJARAN PPKn DI SMP N 2 LENGAYANG
}

\author{
Dasri Rati, Suryanef, Maria Montessori \\ Prodi Pendidikan Pancasila Dan Kewarganegaraan \\ Fakultas Ilmu Sosial Universitas Negeri Padang \\ E-Mail:dasri.rati021296@gmail.com
}

\begin{abstract}
The purpose of this study was to describe the implementation of formative assessment in PPKn learning in SMP N 2 Lengayang. Identify how the implementation of formative assessment in PPKn learning in SMP N 2 Lengayang, and what obstacles the teacher encountered in the implementation of formative assessment in PPKn learning in SMP N 2 Lengayang. The research was conducted by the dilator because the formative assessment carried out was not too formal, and the formative assessment carried out still varied among teacers. And not all teachers understand the role and function of formative assessment. It's just by using remedial, homework, and assignments to monitor student learning outcomes. This type of research is qualitative, the determination of research informants by purposive sampling. Data collection techniques used are observation, interview, document analiysis techniques. Data analysis techniques used are data collection, data reduction, data presentation and coclusion drawing.
\end{abstract}

Keywords: Implementation of Formative Assessment, In Learning PPKn

\begin{abstract}
Abstrak
Penelitian ini dilatarbelakangi karena penilaian formatif yang dilakukan tidak terlalu formal, dan penilaian formatif yang dilakukan masih terdapat beberapa kendala yang ditemui guru pada saat belajar mengajar, dan belum semua guru memahami tentang peran dan fungsi penilaian formatif tersebut. Hanya saja dengan menggunakan tes ulangan harian, penilaian pada saat pembelajaran dan penilaian saat lisan. Tujuan penelitian ini adalah untuk mendeskripsikan tentang pelaksanaan penilaian formatif dalam pembelajaran PPKn di SMP N 2 Lengayang. Mengidentifikasikan bagaimana pelaksanaan penilaian formatif dalam pembelajaran PPKn di SMP N 2 Lengayang, dan kendala apa saja yang ditemui guru dalam pelaksanaan penilaian formatif dalam pembelajaran PPKn di SMP N 2 Lengayang. Jenis penelitian ini adalah kualitatif, penetapan informan penelitian secara purposive sampling. Teknik pengumpulan data yang digunakan adalah
\end{abstract}


dengan teknik observasi, wawancara, analisis dokumen. Teknik analisa data yang digunakan adalah dengan pengumpulan data, reduksi data, penyajian data dan penarikan kesimpulan. Hasil penelitian menunjukan bahwa dalam pelaksanaan penilaian formatif dalam pembelajaran PPKn di SMP N 2 Lengayang yaitu melalui tes tertulis seperti essay dan pilihan ganda atau objektif dan tidak tertulis seperti tes lisan dan presentasi.

Kata kunci: Penilaian, Formatif, Pembelajaran PPKn

\section{PENDAHULUAN}

Salah satu konteks pembelajaran adalah penilaian. Penilaian adalah proses pengumpulan dan pengolahan informasi untuk mengukur pencapaian hasil belajar peserta didik " (Permendikbud Nomor 23 Tahun 2016 Tentang Standar Penilaian Pendidikan). Dengan kata lain, untuk mengukur pencapian hasil belajar peserta didik, guru melakukan penilaian hasil belajar. Penilaian hasil belajar tersebut dilakukan secara terencana dan sistematis. Artinya, terdapat serangkaian proses yang harus dilalui guru ketika melakukan penilaian hasil belajar peserta didik mulai dari tahap perencanaan, pelaksanaan, pengolahan, pemanfaatan/penindaklanjutan, dan pelaporan penilaian. Selain itu, tentunya terdapat prinsip-prinsip penilaian yang dijadikan pedoman bagi guru dalam melaksanakan proses penilaian hasil belajar peserta didik. Prinsip tersebut yaitu, sahih, objektif, adil, terpadu, terbuka, menyeluruh dan berkesinambungan, sistematis, beracuan kriteria, serta akuntabel (dalam Permendikbud Nomor 53 Tahun 2015 Penilaian Hasil Belajar oleh Pendidik dan Satuan Pendidikan pada Pendidikan Dasar dan Pendidikan Menengah, Pasal 5). Sehingga terdapatnya validitas, dan reabilitas dalam penilaian untuk mencapai tujuan penilaian.

Secara umum penilaian dapat dibagi menjadi dua yaitu, penilaian formatif dan penilaian sumatif. Penilaian formatif adalah penilaian yang dilaksanakan ditengah-tengah atau pada saat berlangsungnya proses pembelajaran, yaitu dilaksanakan pada setiap kali satuan pembelajaran atau sub pokok bahasan dapat diselesaikan dengan tujuan untuk mengetahui sejauh mana peserta didik "telah terbentuk" sesuai dengan tujuan pengajaran yang telah ditentukan (Sudijono, 2007:25).

Penilaian formatif diberikan secara periodik untuk memantau kemajuan belajar peserta didik selama proses pembelajaran. Penilaian formatif dipergunakan untuk mengetahui kelemahan-kelemahan yang memerlukan perbaikan, dan dengan demikian penilaian formatif yang 
dimaksudkan, agar hasil pembelajaran menjadi lebih baik.Sedangkan penilaian sumatif yaitu biasanya diberikan pada akhir tahun ajaran atau akhir tahun suatu jenjang pendidikan. Penilaian sumatif dimaksudkan untuk memberikan nilai yang menjadi dasar untuk mengambil keputusan apakah seorang peserta didik dapat dinyatakan naik kelas atau lulus dan diberikan ijazah, karena telah menyelesaikan program atau jenjang pendidikan tertentu. Penilaian sumatif merupakan penilaian akhir tahun atau penilaian akhir jenjang pendidikan.Ruang lingkup penilaian sumatif harus luas dan mencakup seluruh bahan yang diprogramkan sepanjang tahun atau sepanjang jenjang pendidikan.Tingkat kesukarannya pun perlu bervariasi (Daliman, 2013: 2-3).

Artikel ini bertujuan untuk menjelaskan bagaimana pelaksanaan penilaian formatif dalam pembelajaran PPKn, dan kendala apa saja yang ditemui oleh guru dalam melaksanaan penilaian formatif dalam pembelajaran PPKn. Hal ini dikarenakan pelaksanaan penilaian formatif sangat berperan penting dalam dalam memberikan penilaian terhadap peserta didik, salah satunya dengan guru memberikan pengayaan terhadap peserta didik.

\section{METODE PENELITIAN}

Metode dalam penelitian ini menggunakan metode kualitatif, lokasi penelitian di SMP N 2 Lengayang.Adapun informan dalam penelitian ini adalah Kepala Sekolah, Wakil Kepala Sekolah, Guru PPKn, dan Peserta Didik.Teknik pengambilan data dilakukan melalui wawancara, observasi dan dokumentasi.Untuk mendapatkan keabsahan data, dalam penelitian ini peneliti menggunakan teknik ketekunan pengamatan dan teknik tringulasi. Data yang diperoleh dianalisis dengan tahapTeknik pengumpulan data, reduksi data, penyajian data dan penarikan kesimpulan.

\section{HASIL DAN PEMBAHASAN}

1. Pelaksanaan Penilaian Formatif Dalam Pembelajaran PPKn Di SMP N 2 Lengayang

Secara umum penilaian dapat dibagi menjadi dua yaitu, penilaian formatif dan penilaian sumatif. Penilaian formatif adalah penilaian yang dilaksanakan ditengah-tengah atau pada saat berlangsungnya proses pembelajaran, yaitu dilaksanakan pada setiap kali satuan pembelajaran atau sub pokok bahasan dapat diselesaikan dengan tujuan untuk mengetahui sejauh mana peserta didik "telah 
terbentuk" sesuai dengan tujuan pengajaran yang telah ditentukan (Sudijono, 2007:25).

Penilaian formatif diberikan secara periodik untuk memantau kemajuan belajar peserta didik selama proses pembelajaran. Penilaian formatif dipergunakan untuk mengetahui kelemahan-kelemahan yang memerlukan perbaikan, dan dengan demikian penilaian formatif yang dimaksudkan, agar hasil pembelajaran menjadi lebih baik.Sedangkan penilaian sumatif yaitu biasanya diberikan pada akhir tahun ajaran atau akhir tahun suatu jenjang pendidikan. Penilaian sumatif dimaksudkan untuk memberikan nilai yang menjadi dasar untuk mengambil keputusan apakah seorang peserta didik dapat dinyatakan naik kelas atau lulus dan diberikan ijazah, karena telah menyelesaikan program atau jenjang pendidikan tertentu. Penilaian sumatif merupakan penilaian akhir tahun atau penilaian akhir jenjang pendidikan.Ruang lingkup penilaian sumatif harus luas dan mencakup seluruh bahan yang diprogramkan sepanjang tahun atau sepanjang jenjang pendidikan.Tingkat kesukarannya pun perlu bervariasi (Daliman, 2013: 2-3).

Dalam hal ini pelaksanaan penilaian formatif dilakukan Dalam hal guru PPKn SMP N 2 Lengayang sudah melaksanakan berbagai cara untuk memperoleh informasi hasil belajar peserta didik baik pada aspek kognitif maupun afektif. Sebelum melaksanakan penilaian formatif terlebih dahulu guru merancang perencanaan pembelajarannya.

Menurut Carrey (2015) dalam buku (Amirudin, 2016: 49-50), ada tiga fase pokok penilaian formatif, yaitu (1).Fase perorangan atau fase klinis.Pada fase ini perancang bekerja dengan siswa secara perseorangan untuk memperoleh data guna menyempurnakan bahan pembelajaran.Data yang dimaksud disini biasanya kesalahankesalahan. (2). Fase kelompok kecil, yaitu sekelompok siswa yang terdiri atas delapan sampai sepuluh orang yang merupakan wakil cerminan populasi sasaran mempelajari bahan secara mandiri, dan kemudian di uji untuk memperoleh data yang diperlukan. (3). Fase uji lapangan. Boleh diikuti oleh banyak siswa, sering 30 orang sudah mencukupi.Tekanan dalam uji coba lapangan ini adalah pada pengujian prosedur yang diperlukan untuk memberlakukan pembelajaran itu dalam suatu keadaan yang sangat nyata mungkin.Mengapa dilakukan penilaian kelompok kecil, karena untuk mengetahui keefektifan perubahan yang telah dibuat, dan untuk mengetahui masalah-masalah yang dihadapi anak didik jikamenggunakan bahan tersebut.Dan uji coba dilapangan juga dilaksanakan karena tujuannya untuk mengetahui apakah perubahan-perubahan yang telah dibuat dari hasil 
penilaian perseorangan dan penilaian kelompok kecil telah efektif jika digunakan dalam keperluan pembelajaran.

Maka dapat digambarkan bentuk penilaian formatif yang dilakukan oleh guru PPKn di SMP N 2 Lengayang untuk menutupi kesalahan-kesalahan atau kekurangan-kekurangan peserta didik dengan carayaitu seperti penilaian tertulis dan penilaian tidak tertulis sebagai berikut:

\section{a. Penilaian Tertulis atau Tes Tertulis}

Tes tertulis merupakan tes dalam bentuk bahan tulisan (baik soal maupun jawabannya). Dalam menjawab soal siswa tidak selalu harus merespon dalam bentuk menulis kalimat jawaban tetapi dapat juga dalam bentuk mewarnai, memberi tanda, menggambar grafik, diagram dan sebagainya (Abdul Majid, 2009: 195).

Tujuan dari penggunaan tes tertulis yaitu, (1).Mendiagnosa siswa (kekuatan dan kelemahan). (2). Menilai kemampuan siswa (keterampilan, pengetahuan dan pengalaman). (3). Memberikan bukti atas kemampuan yang telah dicapai. (4). Menyeleksi kemampuan siswa baik secara individu maupun kelompok. (5). Monitoring standar pendidikan. Selain itu fungsi dari tes tertulis dalam penilaian formatif yaitu, (1). Dilakukan saat berlangsungnya proses belajar mengajar. (2). Dilaksanakan secara periodic. (3). Mencakup semua mata pelajaran yang telah diajarkan. (4). Bertujuan untuk mengetahui keberhasilan dan kegagalan proses belajar mengajar. (5). Dapat digunakan untuk perbaikan dan penyempurnaan proses belajar mengajar (Abdul Majid, 2009: 195-196).

Berdasarkan hal diatas guru PPKn di SMP N 2 Lengayang dalam melakukan penilaian formatif melakukan tes tertulis dengan cara memberi siswa tugas berupa essay, pilihan ganda, remedial.

\section{1) Essay}

Tujuan guru memberikan peserta didik dengan tugas berupa essay yaitu karena hasilnya lebih akurat, setidaknya siswa lebih memikirkan jawabannya dimana setiap siswa mempunyai pendapat yang berbeda-beda, dan juga tujuannya untuk menghindari siswa berbuat kecurangan dalam bentuk apapun. Kelebihan dari tes esay ini yaitu, sangat baik untuk mengukur atau menilai kemampuan menulis dan kreativitas dalam menuangkan pendapat dalam bentuk tulisan., relative mudah dan cepat membuatnya, selain itu juga dapat membuat siswa belajar lebih giat dan sungguh-sungguh.Penilaian pada tes esay ini juga memiliki keterbatasan yang mana yaitu: (1). Hanya dapat memberikan sampel yang terbatas. (2). Sulit 
untuk dinilai. (3). Reabilitasnya rendah baik bagi guru maupun bagi siswa (Farida Yusuf Tayibnapis, 2008: 208-209).

\section{2). Objektif atau Pilihan Ganda}

Sedangkan dengan memberikan tugas berupa pilihan ganda atau objektif, guru tersebut lebih muda mengoreksinya dan tidak membutuhkan waktu lama dan juga bisa diwakilkan pada orang lain. Adapun kelebihan dari tes objektifyaitu: (1). Ekonomis. (2). Conten sampling luas. (3). Realibilitasnya dan validitasnya tinggi. (4). Skorsing mudah. (5). Dapat member insentif, pengetahuan luas, skills dan ability. Sedangkan keterbatasan dari tes objektif yaitu: (1). Tidak mengukur higher mental process. (2). Cendrung hanya mengukur daya ingat saja (recall). (3). Mengabaikan pengukuran kemampuan menulis (writing ability) (Farida Yusuf Tayibnapis, 2008: 217-218).

\section{b. Penilaian Tidak Tertulis atau Tes Tidak Tertulis}

Adapun teknik yang dilakukan guru PPkn di SMP N 2 Lengayang yaitu dengan tes tidak tertulis yaitu dalam pelaksanaan penilaian formatif yaitu pada saat proses pembelajaran.Guru melakukan penilaian pada saat proses pembelajaran dikelas.

\section{1) Tes Lisan}

Pertanyaan lisan merupakan variasi dari tes essay. Manfaat umum dari tes lisan ini yaitu memberi kesempatan pendekatan yang lebih akrab bagi guru terhadap siswanya dan begitu juga sebaliknya.Tes lisan juga dapat menguntungkan siswa, karenamereka dapat meminta penjelasan lebih lanjut apabilapertanyaan yang diberikan kurang jelas (Farida Yusuf Tayibnapis, 2008: 219-221).

\section{2). Presentasi}

Presentasi yaitu tugas yang harus diselesaikan dalam periode/waktu tertentu.Tugas tersebut bentuk investigasi sejak dari pengumpulan, pengorganisasian, pengevaluasian hingga penyajian data. Karena dalam pelakasanaan penilaian dalam presentasi merupakan suatu sara yang penting untuk menilai kemampuan umum siswa dalam semua bidang. Presentasi juga akan memberikan informasi tentang pemahaman dan pengetahuan siswa pada pembelajaran tertentu, kemampuan siswa dalam mengaplikasikan 
pengetahuan, dan kemampuan siswa untuk mengkomunikasikan informasi (Abdul Majid, 2008: 207-208).

Tujuan dilaksanaan penilaian pada saat presentasi guru mungkin menekankan penilaian pada saat presentasi prosesnya dan menguunakannya sebagai sarana utuk mengembangkan keterampilan siswa dalam merencanakan, menyelidiki, dan menganalisis.

\section{2) Kendala Yang Ditemui Guru Dalam Pelaksanaan Penilaian} Formatif Dalam Pembelajaran PPKn di SMP N 2 Lengayang

Kendala yang dihadapi guru dalam melaksanakan penilaian formatifdalam pembelajaran PPKn di SMP N 2 Lengayang yaitu:

a. Dalam pelaksanaan penilaian formatif yang dilakukan guru PPKn di SMP N 2 Lengayang masih mengalami kendala yang mana banyak siswa yang masih malas dalam mengikuti proses belajar mengajar, dan kebanyakan dari siswa yang masih keluar masuk dalam melakukan proses belajar mengajar sehingga sulit bagi guru untuk melakukan penilaian, kurang minat dalam melakukan pembelajran PPKn.

b. Besarnya pengaruh dari luar membuat siswa sering tidak membuat tugas-tugasnya, karena mereka lebih suka keluar, dan mengikuti teman-teman yang lain.

\section{KESIMPULAN}

Berdasarkan temuan penelitian dan pembahasan yang dilakukan dapat disimpulkan:

1. Dalam melaksanakan penilaian formatif dalam pembelajaran PPKn di SMP N 2 Lengayang yang telah dilakukan oleh guru PPKn di SMP N 2 Lengayang dapat disimpulkan bahwa penilaian telah terlaksana namun ada beberapa kendala. Adapun cara yang ditempuh oleh guru untuk melakukan penilaian formtif yaitu:

a. Tes tertulis

Tes tertulis merupakan tes dalam bentuk bahan tulisan (baik soal maupun jawabannya). Dalam menjawab soal siswa tidak selalu harus merespon dalam bentuk menulis kalimat jawaban tetapi dapat juga dalam bentuk mewarnai, memberi tanda, menggambar grafik, diagram dan sebagainya (Abdul Majid, 2009: 195).

1. Essay 
Tujuan diberi tes essay, karena hasilnya lebih akurat, setidaknya siswa leboh memikirkan jawabannya dimana setiap siswa mempunyai pendapat yang berbeda-beda, dan juga tujuannya untuk menghindari siswa berbuat kecurangan dalam bentuk apapun. Kelebihan dari tes essay yaitu sangat baik untuk mengukur atau menilai kemampuan menulis siswa dalam menuangkan pendapat dalam bentuk tulisan, relaitive mudah dan cepat membuatnya, selain itu juga dapat membuat siswa belajar lebih giat dan sungguh-sungguh.

2. Objektif atau pilihan ganda.

Adapun kelebihan dari tes objektif yaitu: (1). Ekonomis. (2). Conten sampling luas. (3). Reabilitas dan validitasnya tinggi. (4). Skorsing mudah. (5). Dapat member insentif, pengetahuan luas, skilss dan ability. Sedangkan keterbatasan dari tes objektif yaitu: (1). Tidak mengukur higher mental process. (2). Cendrung hanya mengukur daya

ingat saja. (3). Mengabaikan pengukuran kemampuan menulis siswa.

b. Tes tidak tertulis

Adapun teknik yang dilakukan guru PPkn di SMP N 2 Lengayang yaitu dengan tes tidak tertulis yaitu dalam pelaksanaan penilaian formatif yaitu pada saat proses pembelajaran.

1. Tes lisan

Tes lisan merupakan variasi dari tes essay. Manfaat umum dari tes lisan ini yaitu member kesempatan pendekatan yang lebih akrab bagi guru terhadap siswanya dan begitu juga sabaliknya. Tes lisan juga dapat menguntungkan siswa, karena mereka dapat meminta penjelasan lebih lanjut apabila pertanyaan yang diberikan kurang jelas.

2. Presentasi

Yang dimaksud dengan tes presentasi yaitu tugas yang harus diselesaikan dalam periode/waktu tertentu. Tugas tersebut bentuk investigasi sejak dari pengumpulan, pengorganisasian, pengevaluasian hingga penyajian data. 
Tujuan dari dilaksanakan penilaian pada saat presentasi, guru menekankan penilaian pada saat presentasi prosesnya dan menggunakannya sebagai sara untuk mengembangkan keterampilan siswa dalam merencanakan, menyelidiki, dan menganalisis.

2. Terdapat beberapa kendala bagi guru PPKn dalam melaksanakan penilaian formatif diantaranya:

a. Menyiapkan soal ujian yang falid, karena penilaian formatif dilakukan sering dalam proses pembelajaran, sehingga guru membuat soal ujian dengan kurang baik dan tidak memenuhi standar, dan mengapa ini menjadi kendala bagi guru PPKn di SMP N 2 Lengayang, karena seringnya penilaian formatif itu dilakukan, contohnya dengan soal objektif, mungkin guru membuat soal yang sangat gampang sehingga tidak valid dan tidak memenuhi standar.

b. Banyaknya jumlah siswa sehingga menjadikan guru susah untuk menilai, atau mengoreksi tugas siswa. Misalnya soal essay dan objektif sehingga guru kurang pas dalam memberikan nilai kepada siswa.

c. Sulit mengalokasikan waktu untuk remedial bagi siswa yang membutuhkan perbaikan nilai.

d. Sulit menilai siswa yang melakukan presentasi dikelas dikarenakan keterbatasan waktu, sehingga guru terkendala dalam melakukan penilaian.

e. Pada saat ujian lisan, sulit bagi guru untuk mengalokasikan waktu yang tepat, sehingga banyak dari peserta didik yang ujian nya ditunda menjadi hari berikutnya. Selanjutnya kendala yang dihadapi guru terhadap sikap siswa dalam memberikan penilaian formatif yaitu:

a. Kurangnya minat belajar siswa dalam melakukan pembelajaran PPKn

b. Besarnya pengaruh dari luar, sehingga siswa-siswa sering keluar masuk dalam proses belajar mengajar.

c.

\section{b. Saran}

Bertitik tolak dari uaraian yang telah dikemukakan sebelumnya dan dari hasil penelitian ini serta kesimpulan yang telah diperoleh, maka dapat dikemukakan saran-saran sebagai berikut: 
1. Dengan waktu yang tersedia untuk mata pelajaran PPKn sebaiknya guru mampu mengolanya dengan baik agar guru juga dapat melakukan penilaian formatif kepada siswa.

2. Sebaiknya guru mengadakan pelatihan tentang penilaian formatif agar gur dapat menerapkan penilaian tersebut dengan baik dan sesuai dengan ketentuan yang ada.

3. Diharapkan kepada peneliti-peneliti berikutnya yang memfokuskan studinya pada penilaian formatif agar lebih mengali pengetahuannya lagi yang berhubungan dengan hal tersebut.

\section{Acknowledgement}

Penelitian ini dapat dilaksanakan dengan baik karena bimbingan dari Bapak Drs. Suryanef, M.Si dan Ibu Dr.maria Mentessori, M. Ed., M.Si kemudian kritik dan saran yang diberikan oleh BapakDr. Akmal, SH, M.Si, Dr.junaidi Indrawadi, M.Pd, dan Ibu Dra. Al Rafni, M.Si

\section{DAFTAR PUSTAKA}

Afrizal. 2016. "Metodelogi Penelitian Kualitataif". Jakarta : Rajawali press.

Amirudin. 2016. “Perencanaan Pembelajaran Konsep dan Implementasi”. Yogyakarta: Paranama Ilmu

Daliman, A. 2013.“Teknik Penyusunan dan Pembakuan Tes Hasil Belajar Ilmu Sosial Serta Pengolahannya". Jakarta: Penerbit Ombak.

Majid, Abdul. 2008. "Perencanaan Pembelajaran Mengembangkan Potensi Guru". Bandung: PT Remaja Rosdakarya.

Sudijono, Anas. 2007. "Pengantar Evaluasi Pendidikan".Jakarta : Raja Gravindo Persada

Tayibnapis, Farida Yusuf. 2008. “Evaluasi Program dan Instrumen Evaluasi untuk Program Pendidikan dan Penelitian". Jakarta : Rineka Cipta. 